\title{
EVALUATION OF POLYHERBAL UNANI SHAMPOO USED IN DANDRUFF
}

\author{
SHAFIA MUSHTAQ ${ }^{1 *}$, F. ZAMAN ${ }^{2}$
}

${ }^{1}$ Specialist (N.A.M), Department of Indian System of Medicine, Government Unani Hospital Shalteng, srinagar, Jammu and Kashmir, India. 2Department of Moalajat, Jamia Hamdard, New Delhi, India. Email: Shafiya.mushtaq786@gmail.com

Received: 01 December 2021, Revised and Accepted: 10 January 2022

\section{ABSTRACT}

Objective: The objective of the study was to evaluate the laboratory parameters of polyherbal Unani formulation with simple shampoo base used in seborrheic dermatitis (Huzaz) of scalp.

Methods: Evaluation of test drug formulation with shampoo base was done for its appearance, $\mathrm{pH}$, \% of solid contents, wetting time, density, viscosity, dirt dispersion test, froth test, and skin irritation test.

Results: Polyherbal formulation along with simple shampoo base was dark brown in color, thin in consistency, and with pungent aroma. pH of poly herbal formulation was 8.27 which will have positive effect on greasy and thin hairs. Solid contents were moderately easy to wash. Wetting time was $200 \mathrm{~s}$, density was $1.17 \mathrm{~g}$, and viscosity was 2.33 moderately good. Froth test showed froth $>8 \mathrm{~cm}$. Skin sensitivity on albino rats showed no allergic reaction.

Conclusion: Polyherbal Unani formulation can be a promising drug with least side-effects and cost-effective in treating dandruff which relapses every now and then.

Keywords: Polyherbal, Huzaz, Unani, Seborrheic dermatitis, Shampoo.

(C) 2022 The Authors. Published by Innovare Academic Sciences Pvt Ltd. This is an open access article under the CC BY license (http://creativecommons.org/ licenses/by/4.0/) DOI: http://dx.doi.org/10.22159/ajpcr.2022v15i2.43929. Journal homepage: https://innovareacademics.in/journals/index.php/ajpcr

\section{INTRODUCTION}

Dandruff (pityriasis capitis, seborrheic dermatitis confined to scalp) is extremely common affliction of scalp, which is characterized by flaking of scalp [1]. Dandruff is often defined as increased scaling of scalp, representing the more active end of physiological desquamation [2].

Dandruff is a disease that has been around for centuries despite several treatment options [3]. In Unani system of medicine, the dandruff is mentioned under the entity Huzaz or Bafa [4]. Huzaz is an Arabic word meaning scales or flakes from scalp which may be accompanied by lesions or papules. Bafa means dryness of scalp [5].

Dandruff affects almost half of population at the pre-pubertal age and of any gender and ethnicity. No population in any geographical region would have passed through freely without being affected by dandruff at some stage in their life [6].

Huzaz affects aesthetic value and often cause itching. There are various treatments in Western medicine but relapse of this disease is not treated effectively. The various treatment options available are antiinflammatory, anti-fungal, antibacterial, steroids, etc. However, these medicines cause known side effects such as it increases itching, dryness, erythema, hypertrichosis, perioral dermatitis, and eye irritation which limit their usage. Huzaz is relapsed every now and then; its severity may also fluctuate with season as it often worsens in winter. Thus cost effective treatment is need of an hour. Thus, proper treatment of dandruff is also challenging for herbal world. In the present study, a Unani formulation was selected having drugs; Nakhood (Cicer arietinum), Baqila (Vicia faba), Turmus (Lupinous albus), Khatmi (Althea officinalis), and Methi (Trigonella foenum). These drugs are known to have antibacterial, antiinflammatory, and antifungal as well as anti-dandruff activity. As already established that the line of the treatment of dandruff is based on foresaid action and selected formulation fulfills the criteria. Keeping all these properties in mind, it was intended to evaluate the Unani formulation used in Huzaz on modern scientific parameters.

\section{METHODS}

\section{Authentication}

Collection of plant

Plants used in the formulation were bought from Khari Baoli market, wholesale market of herbs in Delhi.

\section{Botanical identification}

The sample of drugs was given to Department of Botany, Jamia Hamdard for its identification. Identification was done with respect to its morphological characters and drugs were found to be authentic and identified as the same to be used.

\section{Preparation of the test drug formulation}

An aqueous extract of drugs with equal quantities with simple shampoo base was prepared. $[4,7]$ Unani formulation was selected having equal quantity, that is, $10 \mathrm{~g}$ each of Nakhood (C. arietinum), Baqila (V. faba), Turmus (L. albus), Khatmi (A. officinalis), and Methi (T. foenum).

Aqueous extract of the above mentioned drugs in equal proportion was taken out by reflux distillation method. Each drug was cleaned, powdered, or crushed before use. Then, $50 \mathrm{~g}$ of test formulation was added with $200 \mathrm{ml}$ of distilled water (1:4).

Heating mental was maintained at temperature below $60^{\circ}$ for $5-6 \mathrm{~h}$, after that, the extract was filtered with muslin cloth. The extract obtained was measured and was found approximately $250 \mathrm{ml}$ each time. Then, this extract was dried on heating mental at temperature below $60^{\circ}$ to its $1 / 5^{\text {th }}$ of volume, thus obtaining $50 \mathrm{ml}$. Then, it was further reduced to $1 / 3^{\text {rd }}$ in hot air oven, at a controlled temperature below $60^{\circ}$, thus desirable dose of $16.6 \mathrm{ml}$ was obtained. Final volume obtained was $16.60 \mathrm{ml}$. Total dose of formulation with simple shampoo base for once application $=25 \mathrm{ml}$. Hence, simple base of shampoo to be added per dose $=8.4 \mathrm{ml}$. 
Stratum corneum, normal or even hydrated, is a most impermeable biological membrane; this is one of important features in living systems. Stratum corneum has distinct lipid and protein domain which is lipophillic in nature and hydrophobic.

The important factors for penetration of drug in the skin are: [8]

1. Concentration of drug

2. Relative affinity of drug for skin and vehicle

3. Diffusion through barriers.

Since this Unani formulation is aqueous in nature and it is understood that aqueous extract is not going to absorb into the scalp.

Due to this reason, we used base (trietanolamine, lauryl sulphate, sodium citrate, glycerol, methyl paraben, calcium alginate, and perfume. A thorough literature review of these base ingredient revealed that they are inert with respect to desired action and also save to use.

\section{Evaluation of test drug formulation with simple shampoo base Appearance}

Visual inspection of sample was done for color and consistency and impurity was done.

$p H$

The $\mathrm{pH}$ of shampoo solution $10 \%$ was determined using $\mathrm{pH}$ meter.

\section{Percentage of solid contents}

Test drug formulation with simple shampoo base (approximately $10 \mathrm{ml}$ ) was placed in a clean evaporating dish. The weight of dish and shampoo was determined. The liquid portion was evaporated in an oven at $105^{\circ} \mathrm{C}$. The reading was taken after half an hour and then after $1 \mathrm{~h}$ until three readings were constant.

\section{Wetting time}

The canvass paper was cut into 1 inch diameter and weight was measured. The disc was floated into the surface of shampoo solution $1 \%$ and the stopwatch was started. The time required for disc to sink was measured accurately and noted as wetting time.

\section{Density}

Weight of a clean and dry $28 \mathrm{ml}(\mathrm{v}$ ) graduated cylinder (a) was taken. Test formulation was added to already weigh $28 \mathrm{ml}$ graduated cylinder. Now carefully, weight of liquid within the cylinder (b) was read and recorded. Weight of cylinder and liquid was taken and then the density of the liquid $\left(b-a / v=d_{1}\right)$ was calculated. Procedure was repeated to find mean density of water $\left(d_{2}\right)$ to help in measuring viscosity.

\section{Viscosity}

The instrument used for measuring viscosity was glass capillary viscometer or Ostwald viscometer at controlled temperature bath. Liquid was drawn into the upper bulb by suction, than allowed to flow down through the capillary into the lower bulb. Two marks (one above and one below the upper bulb) indicated a known volume. The time required for the test liquid to flow through a capillary of a known diameter of a certain factor between two marked points was measured. By multiplying the time taken by the factor of the viscometer, the kinematic viscosity was obtained by calculation;

$\Delta \mathrm{P}=\mathrm{dgh}$

$\eta=$ Adt where $\mathrm{A}$ is a querall constant

$\eta=\frac{\pi \mathrm{r} 4 P t}{8 \mathrm{VL}}$

For two liquids:

$\eta_{1} / \eta_{2}=\mathrm{d}_{1} \mathrm{t}_{1 /} \mathrm{d}_{2} \mathrm{t}_{2}$

$\eta_{1}=$ viscosity of $x$ liquid $\eta_{2}=$ viscosity of water

$\mathrm{d}_{1}$ and $\mathrm{d}_{2}=$ density of $\mathrm{x}$ liquid and water

$t_{1}$ and $t_{2}=$ time of $x$ liquid and water in sec.

\section{Dirt dispersion test}

Two drops of shampoo were added in $10 \mathrm{ml}$ of distilled water in test tube. One drop of Indian ink was added to it and shaken 10 times. The amount of ink was estimated as none, light, moderate, or heavy.

Froth test

At room temperature, $1 \%$ of $25 \mathrm{ml}$ of shampoo solution was put into a 250-ml graduated cylinder, which was then covered by hand and shaken 10 times. The total volume of the foam content after $1.0 \mathrm{~min}$ of shaking was recorded. The height of the foam generated was measured immediately. To evaluate foam stability, the same procedure was performed and the foam volume after 20 min was measured.

\section{Skin sensitivity test}

Animals (albino wistar rats) were collected F/200 g from the central animal house Jamia Hamdard. Ethical approval to conduct this experiment was obtained from Institutional Animal Ethics Committee (IAEC) with reference no. 1158. Animals were kept for maximum duration of 1 month in the central animal house Jamia Hamdard New Delhi. Experiment was performed soon after the ethical approval from IAEC.

Day before the experiment, the hairs on the back side area of rats were removed with the help of soft gillete blade. The animals were divided into two groups, three rats in test group and two in control. Test group was applied with formulation for $15 \mathrm{~min}$ on nude skin. Other group was considered as reference. The animals were observed up to $72 \mathrm{~h}$. The application sites were graded according to the visual scoring scale always by same investigator. The erythema scale was as follows: 0 . None, 1 . Slight, 2. Well defined, 3. Moderate, 4. Scar formation, and 5. Severe. The Fig. 1 shows the bald patch after removing hairs in all five rats (Fig. 1). The animals were returned to animal house soon after experiment.

\section{RESULTS AND DISCUSSION}

\section{Appearance}

Color, consistency, and smell of test formulation have been found to be dark brown, thin, and pungent, respectively.

\section{pH}

The $\mathrm{pH}$ of test formulation has been found to be 8.27. In alkaline $\mathrm{pH}$, hair has increased capacity to absorb water. Water penetrates the scales that open; hydrating the strand and breaking the hydrogen bonds thus can help in removing scale but at same time may cause damage to hair

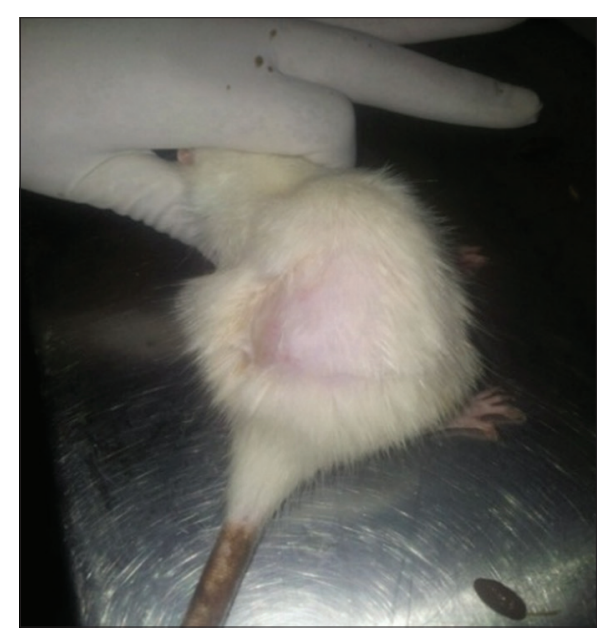

Fig. 1: Before treatment 




Fig. 2: Test formulation applied



Fig. 3: After 15 min of applying test formulation

protein keratin. For extremely greasy and thin straight hair, it may have a positive effect, of adding volume to the hair [9]. It has been found by Matousek et al., 2003 that pH higher that eight help in inhibition of fungal elements on skin [10].

\section{Percentage of solid contents}

If too much of solid content in shampoo then it is difficult to wash out. The test formulation had $20.58 \%$ of solid content which was easy to wash.

\section{Wetting time}

Less the wetting time more will be detergent action. The wetting time of formulation by disc method was $200 \mathrm{~s}$ which is moderately good enough for desirable action.

\section{Density}

More the density of test formulation difficult it would have been to work with. The density of formulation has been found little higher than water, that is, $1.17 \mathrm{~g}$ which is easy to work with.

\section{Viscosity}

The viscosity of liquid defines and control many things such as self-life, packing stability, and its rate of spread after applying. The viscosity of test formulation has been found to be 2.33 which was moderately good.

\section{Dirt dispersion test}

Light impression of ink was found in the test tube containing $10 \mathrm{ml}$ solution of formulation.

\section{Froth test}

Test drug showed the positive results. It showed froth that was higher than $8 \mathrm{~cm}$ that persists for more than half an hour. After half an hour, it regressed to $5 \mathrm{~cm}$ and after $1 \mathrm{~h}-3 \mathrm{~cm}$.

\section{Skin irritation test}

After 15 min of applying test formulation on three albino rats and comparing it with control, it was observed that test group showed no redness or erythema. The animals were kept under observation for $72 \mathrm{~h}$ and no allergic reaction was noted (Fig. 1-3).

Skin irritation test on Wistar albino rats.

\section{CONCLUSION}

Dandruff is most common cause of itchy scalp thus causing great embarrassment and self-consciousness to the sufferer in public, thus affecting the self-esteem and confidence of an individual [11]. The personal care industry conveniently offers its range of products targeting the psychological aspects of dandruff through carefully planned advertisements and various products for dandruff. Despite the fact that dandruff is well controlled by large range of products available in market, there are various side effects because of these easily available products such as hair fall, dryness of hair, loss of hair smoothness, frizzy hair, decreased hair combing ease, depigmentation of scalp, and many more [12]. Another important aspect is less tolerability of these products because of prolonged use, as dandruff is a very much recurrent problem that can affect any individual every now and then throughout the life. Thus, dandruff is well known commercially exploited skin disease by personal care industry [6].

Therefore, search for a safe and cost-effective treatment still continue to exist. The effective treatment for dandruff/Huzaz has been well established in classical Unani literature and is being used since centuries.

Unani formulation used topically, in Huzaz having, a composition of Nakhood (C. arietinum), Baqla (V. faba), Turmus (L. albus), Khatmi (A. officinalis), and Meethi ( $T$. foenum) was selected as test drug [4,7]. In classical Unani literature, almost all of these drugs have been mentioned as having detergent, anti-inflammatory, antibacterial, antiulcer, and analgesic action [13-16].

To re-validate the above formulation in the management of dandruff on modern scientific parameters, the present study was designed to evaluate test drug polyherbal formulation for its appearance, $\mathrm{pH}$, evaluation of test drug formulation with shampoo base was done for its appearance, $\mathrm{pH}, \%$ of solid contents, wetting time, density, viscosity, dirt dispersion test, froth test, and skin irritation test. Evaluation of polyherbal formulation along with simple shampoo base was dark brown, thin in consistency, and had pungent aroma. $\mathrm{pH}$ of polyherbal formulation was 8.27 which will have positive effect on greasy and thin hairs. Solid contents were moderately easy to wash. Wetting time was $200 \mathrm{~s}$, density was $1.17 \mathrm{~g}$, and viscosity was 2.33 moderately good. Froth test showed froth greater than $8 \mathrm{~cm}$. Skin sensitivity on albino rats showed no allergic reaction. Thus, it can be concluded polyherbal Unani formulation can be a promising drug with least side-effects and cost-effective in treating dandruff which relapses every now and then.

\section{ACKNOWLEDGMENT}

I am thankful to school of unani medicine, Jamia hamdard, Department of botany, Jamia Hamdard, New Delhi; Department of biochemistry, Jamia Hamdard, New Delhi; Department of pharmacognosy and pharmaceutics, Jamia Hamdard, New Delhi to carry out this study as a part of my MD thesis.

\section{AUTHORS CONTRIBUTION}

The coauthor helped me in the preparation of the article by reviewing and editing it. 


\section{CONFLICT OF INTEREST}

The authors hereby declare there are no conflicts of interest.

\section{AUTHORS FUNDING}

Project was part of M.D. thesis there was no funding agency involved.

\section{REFERENCES}

1. Weedon D. Weedon's Skin Pathology. $3^{\text {rd }}$ ed. China: Churchill Livingstone, Elsevier; 2010. p. 110.

2. Amdt KA, Hsuj T. Manual of Dermatologic Therapeutics. $7^{\text {th }}$ ed. Philadelphia, PA: Lippincott Williams and Wilkins; 2007. p. 180-4.

3. Shuster $\mathrm{S}$. The etiology of dandruff and the mode of action of therapeutic agents. Br J Dermatol 1984;111:235-42.

4. Kabiruddin H. Bayaz-E-Kabir. Vol. 1. Hyderabad: Hikmat Book Depot; 1938. p. 319

5. Ferozudin. Jamiaul Ferozul Lugat. New Delhi: Farid Book Depot; 1987. p. 207.

6. Ranganathan S, Mukhopadhyay T. Dandruff: The most commercially exploited skin disease. Indian J Dermatol 2010;55:130-4
7. Khan A. Qarabedeen Azam. New Delhi: Aijaz Publication; 1996. p. 350 .

8. Martin A. Physical Pharmacy. $4^{\text {th }}$ ed. New Delhi: Waverly Publishing House; 1994. p. 346-50.

9. Dias MF, de Almeida AM, Cecato PM, Adriano AR, Pichler J. The shampoo $\mathrm{pH}$ can affect the hair: Myth or reality? Int J Trichol 2014;6:95-9.

10. Matousek JL, Campbell KL, Kakoma I, Solter PF, Schaeffer DJ. Evaluation of the effect of $\mathrm{pH}$ on in vitro growth of Malassezia pachydermatis. Can J Vet Res 2003;67:56-9.

11. Rippon JW. Medical Mycology: The Pathogenic Fungi and Pathogenic Actinomycetes. Philadelphia, PA: WB Saunders Co.; 1984. p. 154-68.

12. Kelly AP, Taylor SC. Dermatology for Skin of Color. New Delhi: McGraw Hill Publication; 2009. p. 244

13. Sina I, Fit-Tibb AQ, Kinturi GH. Pakistan, Lahore: Shaikh Mohammad Bashir \& Sons; 1927. p. 103, 104, 106, 211, 219.

14. Baytar I. Al-Jamili Mufradat Al Adwiya Wal Aghzia. Vol. 1. New Delhi: CCRUM; 1997. p. 284

15. Lubhaya R. Goswami Bayanul Advia. Vol. 2. New Delhi: Kuwo Noor Press; 1975. p. 227.

16. Ghani N. Khazainul Advia. Vol. 2. Lahore: Diamond Publisher; 1921. p. $518-22$. 